\title{
Bilateral pneumothoraces, pneumomediastinum and subcutaneous emphysema as a rare complication of endoscopic cholangiopancreatography
}

\author{
Till Plönes, ${ }^{1}$ Anna-Kristina Reuland, ${ }^{2}$ Bernward Passlick ${ }^{1}$ \\ ${ }^{1}$ Department of Thoracic Surgery, University Medical Center Freiburg, Freiburg, Germany \\ ${ }^{2}$ Department of Hematology and Oncology, University Medical Center Freiburg, Freiburg, Germany \\ Correspondence to Dr Till Plönes, Till.Ploenes@uniklinik-freiburg.de
}

\section{DESCRIPTION}

A 67-year-old woman underwent endoscopic cholangiopancreatography (ERCP) for elective exchange of a bile duct stent. The ductus hepaticus communis was stented because of a bilary stricture of unknown aetiology for the first time half a year ago. Multiple previous performed ERCPs were without any complications and show no unexpected findings. The previously placed stent was extracted and replaced by a new 10 French stent. The patient remained stable through the intervention with close monitoring and there were no complications. Immediately after the intervention, the patient developed a progressive dyspnoea. She was tachypnoeic and physical examination revealed subcutaneous emphysema of the thorax and the neck (figure 1). Heart and lung sounds were noticeably decreased. A CT with oral contrast indicated a perforation of the oesophagus as the cause of bilateral pneumothoraces, pneumomediastinum and subcutaneous emhysema (figure 2). The patient was admitted to the intensive care unit where a chest tube was

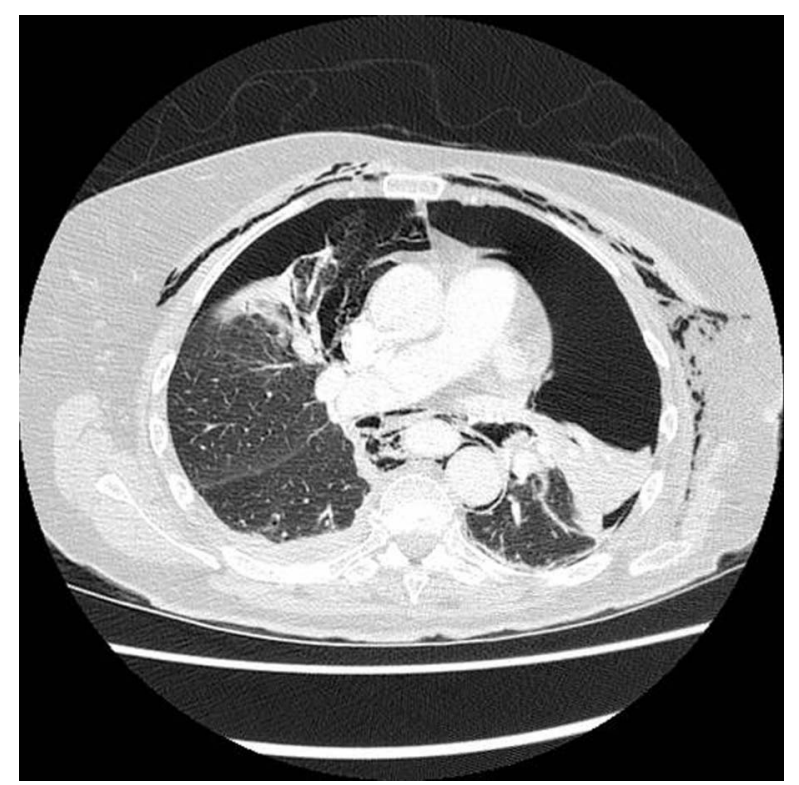

Figure 1 Bilateral pneumothoraces, pneumomediastinum and subcutaneous emhysema after ERCP.

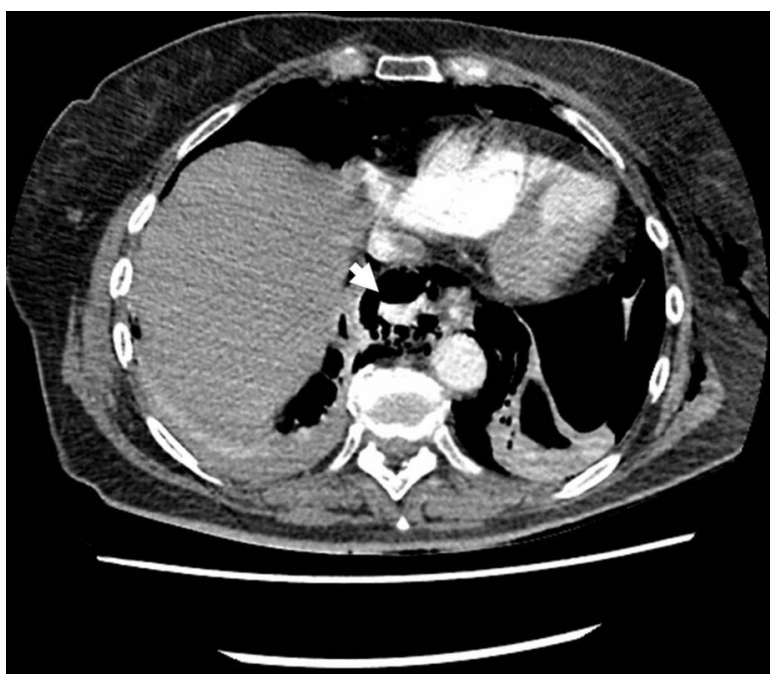

Figure 2 The CT demonstrates a perforation of the oesophagus with a paraesophageal depot of contrast agents (shown by the arrow).

placed and an endoscopic re-evaluation was performed. Intraluminal, there was no hint for perforation. Under non-surgical management, bilateral pneumothoraces, pneumomediastinum and subcutaneous emhysema were regredient and the patient was discharged asymptomatic after 9 days. ERCP is a widely used diagnostic and therapeutic tool in gastrointestinal daily practice. Most complications are rare with a complication rate of $4-10 \%$ and a mortality of $0.4 \% .{ }^{1}$ Complications of ERCP include postinterventional pancreatitis, haemorrhage, cholangitis and perforation. However, bilateral pneumothraces, pneumomediastinum and subcutaneous emphysema after ERCP are very rare in the literature and till now there have been only four cases reported. ${ }^{2} 3$

\section{Learning points}

- Endoscopic cholangiopancreatography can cause serious complications even if this is rare.

- This rare complication should be managed by non-surgical treatment. 


\section{BMJ Case Reports}

\section{Competing interests None}

Patient consent Obtained

\section{REFERENCES}

1. Loperfido S, Angelini G, Benedetti G, et al. Major early complications from diagnostic and therapeutic ERCP: a prospective multicenter study. Gastrointest/ Endosc 1998;48:1-10.
2. Sampaziotis F, Wiles A, Shaukat S, et al. Bilateral pneumothorax and subcutaneous emphysema following endoscopic retrograde cholangiopancreatography: a rare complication. Diagnostic Therapeutic Endosc 2010. Epub 2010/09/10.

3. Brueck M, Bandorski D, Rauber K, et al. Pneumoretroperitoneum und beidseitiger Pneumothorax nach endoskopischer Sphinkterotomie. (Pneumoretroperitoneum and bilateral pneumothorax after endoscopic biliary sphincterotomy]. Dtsch Med Wochenschr 2010;135:853-6.

Copyright 2012 BMJ Publishing Group. All rights reserved. For permission to reuse any of this content visit http://group.bmj.com/group/rights-licensing/permissions.

BMJ Case Report Fellows may re-use this article for personal use and teaching without any further permission.

Please cite this article as follows (you will need to access the article online to obtain the date of publication).

Plönes T, Reuland A-K, Passlick B. Bilateral pneumothoraces, pneumomediastinum and subcutaneous emphysema as a rare complication of endoscopic cholangiopancreatography. BMJ Case Reports 2012;10.1136/bcr-2012-007412, Published XXX

Become a Fellow of BMJ Case Reports today and you can:

- Submit as many cases as you like

- Enjoy fast sympathetic peer review and rapid publication of accepted articles

- Access all the published articles

- Re-use any of the published material for personal use and teaching without further permission

For information on Institutional Fellowships contact consortiasales@bmjgroup.com

Visit casereports.bmj.com for more articles like this and to become a Fellow 